УДК 94(477)«15/16»

\title{
Тетяна Гошко
}

кандидат історичних наук,

дочент кафедри Класичних, візантійських і середньовічних студій

Українського Католицького Університету,

e-mail:hoshko@ucu.edu.ua

\section{УЯВЛЕННЯ ПРО ДИТИНСТВО У КОДЕКСАХ МІСЬКО- ГО ПРАВА В РЕЧІ ПОСПОЛИТІЙ XVI - ПОЧАТКУ XVII CT.}

Кодекси міського права Речі Посполитої XVI - початку XVII cm. відобразили еволюиію уявлень про дитинство від пізнього середньовіччя до ранньомодерної доби. Хоч вони й посилаються на правові норми попередніх епох, однак містять чимало положень, щуо з'явилися під впливом Гуманізму і Реформації. Внаслідок глибшої християнізаиії моралі на межі Середніх віків і Нового часу утверджується нове ставлення до дитинства як особливого і важливого етапу в житті людини. Тому станом на XVI cm. у правових кодексах з'являються спеціальні статті про дітей. Міське право починає захищати інтереси дітей, розглядаючи різні аспекти, зокрема право ненародженої, але зачатої, дитини, дітей «правдивого ложа», сиріт тощуо, майнові інтереси дитини, ї̈ життя та майбутнє.

Ключові слова: середньовіччя, ранньомодерна доба, Річ Посполита, вік людини, етапи життя, дитинство, кодекси міського права, опіка, повноліття, злочин, кара, вагітна жінка, матеріальні інтереси дітей, діти «правдивого ложа».

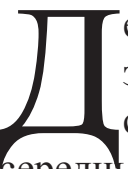

е б не жила людина, вона завжди намагається осмислити і зрозуміти світ, що її оточує, своє місце в ньому, побачити себе як його невід'ємну частину. Не винятком були і люди еередньовіччя та ранньомодерної доби. Оскільки людина змінюється протягом життя, і це помітно як їй самій, так і іншим, тож люди завжди аналізували етапи свого життя. Перший із них - дитинство - набувало різних сенсів у різні історичні періоди. Розуміння дитинства було невіддільне від осмислення інших етапів людського життя.

У цій статті зроблено спробу показати, як кодекси міського права Речі Посполитої XVI - початку XVII ст. відображали еволюцію уявлень про дитинство від пізнього середньовіччя до ранньомодерної доби.

Хоч космос середньовічної людини був надзвичайно тісним, обмеженим та одноманітним, хоч все в ії світі було упорядкованим і мало своє визначене місце, але це була позірна простота, бо цей начебто маленький за розмірами світ у сприйнятті того- 
${ }^{1}$ Гуревич, А. (2007). Избранные труды. Средневековый мир. СПб, С. 72.

2 Арьес, Ф. (1999). Ребенок и семейная жизнь при старом порядке. Екатеринбург, С. 32-33.

${ }^{3}$ Див.: Sears, Е. (1986).

The Ages of Man: Medieval Interpretations of the Life Cycle. Princeton, P. 38-53.

${ }^{4}$ Дари також несли символічні смисли. В Новому Завіті читаємо: «I, ввійшовши до дому, знайшли там Дитятко 3 Марією, Його матір'ю. І вони впали ницьма, і вклонилися Йому. I, відчинивши скарбниці свої, піднесли Йому свої дари: золото, ладан та смирну» (Мт $2,11)$. Ця фраза інтерпритується багатьма дослідниками, і описані дари інтерпретують в різний спосіб. Поширеним $\epsilon$ сприйняття їх як символу земного царства, богослужіння і смерті. Саме такою $є$ інтерпретація цих дарів у пасхальному гімні « We Three Kings» Джона Генри Гопкинса, який став надзвичайно популярним у християнському світі

${ }^{5}$ Див.: O’Neill, Y. (september, 1965). The History of the Publication of Bernard of Gordon's Liber de Conservatione Vitae Humanae. Sudhoffs Archiv für Geschichte der Medizin und der Naturwissenschaften, Bd. 49 (H. 3), 269-279.

${ }^{6}$ Shahar, S. (2004). Growing Old in the Middle Ages. 'Winter Clothes Us in Shadow and Pain'. London; New York, P. 15. Детальний аналіз різноманітних середньовічних і ранньомодерних теорій про стадії людського життя див.: Ibidem, Р. 12-36.

7 Детальніше див.: Гуревич, А. (2005). Индивид и социум на средневековом Западе. М., C. 198 .

${ }^{8}$ Див.: Гошко, Т. (2017). «Саксонське Зерцало»: символи і метафори. УІЖ, № 2, С. 134135. часних людей був неймовірно насиченим. Як зауважив Арон Гуревич, «[п]оряд із земними істотами, предметами і явищами він включав в себе ще й інший світ, породжений релігійною уявою і марновірством. Цей світ 3 нашої теперішньої точки зору можна було би назвати подвоєним, хоч для людей середньовіччя він виступав як єдиний. Про кожен предмет окрім обмежених відомостей, що стосувалися його фізичної природи, існувало ще й інше знання - знання його символічного сенсу, його значення в різних аспектах співвідношення людського світу до світу божественного... Символічне подвоєння світу надзвичайно його ускладнило... Світ символів був невичерпним» ${ }^{1}$. Оскільки люди середньовіччя мислили символічними категоріями, то й на уявлення про людське життя цей символізм, безперечно, накладався. У Свропі він мав яскраво виражене християнське забарвлення і був пов'язаний iз символікою чисел. Це відобразилося і в уявленні про етапи людського життя. Вони були описані у наукових та псевдонаукових трактатах, поетичних творах, відображені в іконографії․ Згодом ці уявлення стали предметом дослідження для сучасних медієвістів ${ }^{3}$.

Одним із найдавніших середньовічних уявлень був поділ людського життя на три фази, що їх символізували три волхви, які прийшли привітати новонародженого Iсуса i принесли йому свої дари 4 . Французький лікар і доктор медицини Бернар де Гордон (1270-1330) у своєму трактаті «Liber de Conservatione Vitae Humanae», виданому у 1308 p..$^{5}$, також поділяє людське життя на три окремі періоди:

1. Aetas pueritiae - від народження до 14 років;

2. Aetas iuventutis - від 14 до 35 років;

3. Aetas senectutis - від 35 років до кінця життя 6 .

У XIII ст. Філіп Новарський у трактаті «Чотири віки людини», в якому виклав свої погляди на виховання людини, провів паралель між етапами людського життя і порами року. Чотиричленний поділ людського життя підтримав і Гіппократ, на думку якого кожному із етапів в житті людини відповідає певний фізіологічний стан - вологість, сухість, тепло чи холод

Однак, найчастіше циклів людського життя виділяли 7, що не дивно, бо саме це число було надзвичайно популярним у середньовіччі і мало символічне значення, про що неодноразово писали дослідники ${ }^{8}$. Ба більше, найчастіше крайні дати окремих періодів людського життя також були кратними 7, рідше іншим числам, які мали символічне значення у біблійних текстах. Зокрема, в середньовічному трактаті «Велике зібрання всілякого роду речей» читаємо: «Перший вік - дитинство (enfance), який саджає зуби, і починається цей вік $з$ народження дитини і продовжується до семи років, і в цьому віці всяка істота називається немовлям, що те саме, що й безмовне - тому що в цьому віці воно не вміє ні говорити, ні складати досконало фрази, так як зуби його ще не зміцніли і не зайняли свого місця, як говорить Ісидор і Константин. За дитинством іде другий вік, який називається pueritia, i називають його так, тому що людина в цьому віці схожа на зіницю ока, як говорить Ісидор, і триває цей вік до чотирнадцяти років. Потім приходить черга третього віку, який називається отроцтвом (adolescence), 
${ }^{9}$ Цит. за: Арьес, Ф. (1999). Ребенок и семейная жизнь при старом порядке, С. 32.

${ }^{10}$ Isidore of Seville, trans. Barney, S. A., Lewis, W. J., Beach, J. A. \& Berghof, O. (2006). The Etymologies of Isidore of Seville. Cambridge, P. 241.

${ }^{11}$ Ibidem, S. 241-243.

12 Преподобный Максим Грек. (n.d.). Разные сочинения. Retrieved December 15, 2017 , from http://www.biblioteka3.ru/ biblioteka/maksim_grek/razn_ soch/txt10.html\#a45

${ }^{13}$ Сказание о сотворении Богом Адама. (n.d.). Retrieved December 15, 2017, from http:// apokrif.fullweb.ru/apocryph2/ adam.shtml

${ }^{14}$ Усачев, А. (2014). «Старость глубокая» в XIV - XVI в.: демографические реалии и их восприятие современниками (на материалах письменных источников). Древняя Русь. Вопросы медиевистики. № 1 (55), C. 60. який триває за Константином в його повчанні до 21 року, а за Ісидором він триває до 28 років, доходячи до 30 і 35 років. Вік цей називається так через те, що людина стає здатною народжувати собі подібних, говорить Ісидор. В цьому віці члени гнучкі і можуть ще рости, отримуючи силу і могутність від природнього тепла. I внаслідок цього людина в цьому віці досягає розмірів і сили, даних їй природою» ${ }^{9}$. Справді, у трактаті Ісидора Севільського виділено шість, але фактично, сім періодів життя людини, бо із шостого виділено окремий, умовно кажучи, підетап - останній період старості. За Ісидором Севільским, вік немовляти триває до семи років, дитинство - до 14, період дорослішання- до 28 років, зрілість у людини наступає у 50 років, а у 70 - старість.: «Періоди людського життя (De aetatibus hominum) 1. С шість періодів у людському житті: немовля, дитина, юнак, молода людина, дорослий i старий. 2. Перший період, вік немовляти (infantia), від народження дитини триває до семи років. 3. Другим періодом є дитинство (pueritia), яке є чистими (purus) роками, протягом якого дитина ще не підходить для дітонародження, і триває він до чотирнадцяти років. 4. Третій період, юність (adolescentia), є зрілим (adultus, ppl. Adolescere), достатнім для дітонародження і триває до двадцяти восьми років. 5. Четвертий період, молодість (iuventus), найсильніший з усіх періодів, закінчується в п'ятдесят років. 6. П'ятий період, життя старої людини (senior), тобто зрілість (gravitas), що є спаданням від юності до старих років, але ще не стара людина... Цей період починається в п’ятдесят і закінчується в сімдесят років. 7. Шостий період є роками старості (senectus), який є не обмеженим роками, навпаки триває стільки життя, скільки призначено після попередніх п’яти періодів для старіння. Senium, однак, являє собою останню частину старості і називається так, тому що це кінець шостого (cf. seni, “six”) періоду. Отже, на ці шість періодів філософи розділили людське життя - періодів, в яких змінюється життя, проходить свій шлях і досягає кінцевої точки смерті» ${ }^{10}$. Далі Ісидор детально пояснює особливості всіх цих шести періодів життя людини ${ }^{11}$.

Теорія про поділ людського життя на сім окремих періодів побутувала і на руських землях, зокрема Максим Грек писав: «Сім ступенів людського віку. Немовля до 3 років, дитинча до 6 років, дитина до 9 років, отрок в 12 років, юнак в 20 років, чоловік в 30 років, старий в 50 років. «Даси частину семи, даси і восьмому» (Еккл., 11, 2), тобто семи ступеням, це нинішньому тлінному життю, даси і восьмий, тобто восьмому майбутньому віку відповідні духовні справи» ${ }^{12}$. Певний відгомін цієї теорії присутній і в популярному апокрифічному тексті «Сказание како сотвори Бог Адама»: «І був Адам у раю сім днів, [як] прообраз [встановлений] Господом Богом життя людського: [коли людині] 10 років виповниться - [це] народження життя, 20 років - юнак, 30 років - повноліття, 40 років - зрілість, 50 років - сивина, 60 років - старість, 70 - кончина» ${ }^{13}$. Як зауважив російський дослідник А.Усачов, тут наводиться дещо інше, в порівнянні з текстами Максима Грека, датування старості ${ }^{14}$, яке однак, перегукується із висновками Ю.Бессмертного про старість у віці 50-60 років для населення Західної 
${ }^{15}$ Бессмертный, Ю. (1991).

Жизнь и смерть в средние века: очерк демографической истории Франции. М., С. 113.

${ }^{16}$ Арьес, Ф. (1999). Ребенок и семейная жизнь при старом порядке, С. 36.

17 Там же, С. 36.

${ }^{18}$ Бастль, Б. (2004). Вік. Новий час. У П Дінцельбахер (Ed.), Історія європейської ментальності. Львів, С. 268.

${ }^{19}$ Childhood. (2017, December 13). Retrieved December 15, 2017, from https://en.wikipedia. org/wiki/Childhood

${ }^{20}$ Дитинство. (n.d.). Retrieved December 15, 2017, from http:// www.psyh.kiev.ua/\%D0\%94\%D $0 \% \mathrm{~B} 8 \% \mathrm{D} 1 \% 82 \% \mathrm{D} 0 \% \mathrm{~B} 8 \% \mathrm{D} 0 \%$ BD $\%$ D1\%81\%D1\%82\%D0\%B2 $\% \mathrm{D} 0 \% \mathrm{BE}$

${ }^{21}$ Groicki, B. (1954). Tytuły prawa majdeburskiego.

Warszawa, S. 195.

${ }^{22}$ Аналіз історіографії питання в європейському контексті див.: Cunningham H. (2014). Children and Childhood in Western Society Since 1500. London, P. 3-17.
Свропи ${ }^{15}$. Отже, теорія про поділ людського життя на окремі періоди відповідно до вікових категорій була доволі популярною у Середньовіччі, причому у різних частинах християнського світу. Тож нічого дивного, що вона знайшла своє відображення і у кодексах міського права XVI - першої половини XVII ст.

В Середньовіччі життя загалом розглядалося як низка етапів, кожен 3 яких відповідав певному виду занять, фізичному типові, обов'язкам і певній моді. Періодизація життя була настільки ж усталеною, як і структури суспільства чи природні цикли ${ }^{16}$. Термінологія, яка позначала ці сім етапів у житті людини була доволі складною, і не завжди можна було в інших мовах знайти відповідники цим термінам. На це вказує один із французьких інтелектуалів в 1556 р.: «Французькою це значно важче, аніж латиною, оскільки латиною сімом періодам життя (за кількістю планет) дано сім різних імен, з яких у французькій мові можна знайти лише три, а саме дитинство, молодість і старість» ${ }^{17}$. Щось подібне можна сказати і про українську мову і характерну для даної проблеми термінологію. А відтак, розуміння уявлень про вікові особливості життя людей в той чи інший період є важливими для розуміння історичного розвитку суспільства загалом. Беатрікс Бастль пише: «Вік людини - одна 3 категорій диференціації людського буття поряд зі статусом, становою належністю і статтю. Стосунки між віковими групами і поколіннями впливають на структуру суспільства і водночас $є$ його продуктом. Хоча фізичний і психічний вік залежить від кожного окремо, проте одночасний розвиток продуктивних та освітніх систем зумовлює відповідний поділ життя, який багато в чому не залежить від окремого індивіда. Отже період життя людини не є якимось однозначним поняттям, це не проста, а хронологічно кількісна величина. Фактично - це крихка, важко доступна концепція» ${ }^{18}$.

Крайніми в цій схемі етапності людського життя були дитинство і старість. У літературі є чимало визначень кожного із цих періодів. Підсумовуючи їх, можна зазначити, що дитинство - це період у житті кожної людини, який триває від народження до підліткового віку, тобто до досягнення статевої зрілості (пубертатного періоду). У психології розвитку у дитинстві виділяють такі етапи: розвитку дитячого віку (навчання ходити), раннє дитинство (ігровий вік), середній дитинство (шкільний вік) та підлітковий вік (період статевого дозрівання після статевого дозрівання) ${ }^{19}$. Окрім того, «у дитинстві поєднані процеси росту, дозрівання, розвитку. Кожен окремий період дитинства характеризується специфічною соціальною ситуацією розвитку, провідним видом діяльності та виникненням новоутворень у психіці й особистості дитини"20.

Дитинство, як і старість, було пов'язано з опікою, якій присвячено було чимало уваги у кодексах міського права. На неї могли розраховувати всі, хто не міг самостійно розпоряджатися своїм життям і майном, той «хто сам собі порадити не може» ${ }^{21}$. Однією iз таких категорій є неповнолітні діти. Питання дитинства і виховання неповнолітніх дітей в історичній перспективі стало особливо популярним із 60-х рр. XX ст., і на сьогодні у світовій історіографії має уже поважну літературу ${ }^{22}$. Що ж до української історіо- 
${ }^{23}$ Ворончук, I. (2014). Інститут опіки: правові норми та повсякденні практики на Волині ранньомодерної доби. Україна в світовій історії. № 3 (52), C. 136 .

${ }^{24}$ Іваницький, С. (1925). Закони про опіку над недолітками в джерелах Магдебурзького права Західньої Руси й Гетьманщини. У Праці Комісіі для виучування історії західньо-руського та вкраӥнського права. Вип. 1. К., С. 59-81.

${ }^{25}$ Сердюк, I. (2009). «Без заплаты, на харчах и одежи хозяйскихъ»: діти в населенні лівобережного українського міста XVIII ст. Краєзнавство. № 1-2, С. 196-202; Сердюк, I. (2012). Дитина і дитинство в Гетьманщині XVIII ст. У Повсякдення ранньомодерної України. Історичні студї в 2-х mомах. (T.1: Практики, казуси та девіаиії повсякдення. С. 57-86). К.; Маслійчук, В. (2010). Вік дорослішання: початок повної кримінальної відповідальності в Лівобережній та Слобідській Україні у другій половині XVIII ст. УІЖ. № 2, С. 38-47; Маслійчук, В. (2011). Дитина на Північному Лівобережжі в другій половині XVIII ст. Сіверянський літопис. № 2, С. 63-68 та ін.

\section{${ }^{26}$ Groick, B. Tytuły prawa} majdeburskiego, S. 195.

${ }^{27}$ Арьес, Ф. Ребенок и семейная жизнь при старом порядке, С. 37.

28 Детальніше див.: Clarke, J. (2004). Histories of Childhood. Y Wyse, D. (ed.) Childhood Studies: An Introduction. Malden, MA; Oxford, UK, P. 5. графії, то почасти можна погодитися із твердженням Ірини Ворончук: «3 точки зору соціальних практик в українській історіографії з'ясовано лише питання опіки над жінками. Проблема опіки над неповнолітніми дітьми в українській історіографії не заторкувалась, хоча тогочасне законодавство і документальний матеріал дають можливість дослідити широкий спектр питань, пов'язаних 3 опікунською практикою над дітьми» ${ }^{23}$. Однак, видається, авторка надто категорична, оскільки питання опіки над дітьми в українській історіографії таки розглядалося, зокрема стосовно міст-магдебургій, в тому числі і на Волині. Першим про опіку над неповнолітніми на руських землях у містах з німецьким правом писав С.Іваницький-Василенко ${ }^{24}$. Щоправда, навіть стосовно міст тема опіки на руських землях далеко не вичерпана. У сучасній українській історіографії доволі активно вивчається опіка над дітьми у XVIII ст. та демографічні характеристики дитинства ${ }^{25}$. Та все ж більшість аспектів цієї теми в українській історіографії таки не досліджена, хоч у розпорядженні дослідників є достатня кількість джерельного матеріалу, пов’язаного з даною проблемою.

Найперше під опіку потрапляли діти, а тому тема опіки напряму була пов'язана із уявленням про дитинство, бо сама опіка над дітьми тривала доти, доки тривало дитинство, тобто до досягнення дитиною віку, який давав їй можливість приймати свідомі рішення і самій відповідати за свої вчинки: «Опіка нічим іншим не $\epsilon$, як владою над людиною, яка залишившись після батьківської смерті, сама собі через свою молодість зарадити не вміє, дана від того, хто чинить тестамент, або від уряду. Аби той, кому така влада дана, мав на своїй праці сироту, керував ним, захищав, виховував як батько, мав його маєтки в управлінні, і розпоряджався ними аж до досягнення сиротою років розторопних» ${ }^{26}$. Навіть більше, як зауважив Філіпп Ар'єс, саме поняття дитинства було пов'язане 3 ідеєю залежності: слова хлопець, синок, гарсон належать до словника феодально-сеньйоріальних відносин залежності. «Дитинство закінчувалось тоді, коли закінчувалась, або ставала меншою залежність» ${ }^{27}$. Щоправда, треба мати на увазі, що Ф.Ар'єс у своєму досліджені говорить не так про реальних дітей і їхнє дитинство, як про сприйняття цього етапу людського життя людьми епохи середньовіччя $^{28}$, як, власне кажучи, і кодекси міського права XVI ст.

В епоху середньовіччя дитинству не було місця, до XII ст. дітей практично не зображали. Тільки у наступному столітті з'явиться кілька дитячих типів в образотворчому мистецтві: ангел, Ісус-немовля, якого найчастіше зображали з Богородицею, оголене дитя. При тому немовля Ісуса в цей час практично ніколи не зображали без пелюшок, його оголять лише наприкінці доби середньовіччя. А у XIII ст. зображення голих немовлят символізували дитячу невинність. Також до цього часу належить зображення душі, яка покидає тіло у вигляді оголеного немовляти. Починаючи 3 XIV ст. тема дитинства Ісуса розвивається, що тісно переплелося iз розвитком культу Богородиці. Саме в цей час в іконографії з'являється тема дитинства інших святих. Все це символізує поступову зміну ставлення до дітей. У XV-XVI ст. з'являються зображення дітей у колі сім’i, а згодом, не пізніше XVI ст., з’являються зобра- 
${ }^{29}$ Детальніше див.: Арьес, Ф. Ребенок и семейная жизнь при Старом порядке, С. 44-48.

${ }^{30}$ До прикладу, у Франції в XVI ст. рівень дитячої смертності становив 30\% серед дітей, яким не виповнилось року, а в XVII ст. він піднявся до 40\% (Ададуров, В. (2002). Історія Франції. Королівська держава та створення нації (від початків до кінця XVIII ст.). Львів, С. 214-215). Дитяча смертність була доволі високою на українських землях і у XVIII ст. Як зауважив Ігор Cердюк, «за даними церков Києво-Печерської лаври, у 1763 році померло 52\% новонароджених дітей, у 1764 - 81\%, у 1765 - 92,3\%». Та навіть 3 тих, хто виживав, віку 5 років досягали лише 42-43\% (Сердюк, I. (2011). Полкових городов обивателі: історико-демографічна характеристика міського населення Гетьманщини другої половини XVIII ст. Полтава, С. 114). Подібні висновки ро- ження дітей на надгробках ${ }^{29}$. Те, що дитинство спершу не розглядалося як важливий етап життя, радше за все було пов'язано із високою дитячою смертністю ${ }^{30}$. Слушно зауважив Філіпп Ар'єс: «Думка про збереження образу дитини не виникала, якщо дитина вижила і стала дорослою, або якщо померла немовлям. У першому випадку дитинство - всього лиш перехідний період, пам'ять про який не варто фіксувати; в другому випадку, у випадку смерті дитини, рання кончина чогось малого не заслуговувала запам'ятовування - дітей багато і далеко не всі переживуть критичний період! Таке ставлення переважало доволі довгий час, і люди намагалися народжувати якомога більше дітей, щоб зберегти 3 них хоча би кількох» ${ }^{31}$.

Поява у XVI ст. посмертного зображення дитини стала свідченням зміни чуттєвого ставлення до неї. Хоча в цей період дитячі портрети, окрім посмертних на надгробках, були рідкістю, але вже в наступному столітті вони стають доволі поширеними, що означало, що змінюється ставлення до дитинства і з'являється потреба зафіксувати неповторні риси дитини, які є швидко минущими. «Таким чином, незважаючи на те, що демографічні умови не зазнали кардинальних змін від XIII до XVII ст., і те, що дитяча смертність залишається на доволі високому рівні, ці тендітні істоти сприймаються по-новому, і за ними визнається право бути чимось особливим, право, в якому їм відмовляли раніше, - так наче суспільна свідомість лише тепер відкрила для себе, що душа дитини теж безсмертна. Абсолютно очевидно, що нове значення, яке надавали особі дитини, пов’язано з більш глибокою християнізацією моралі» ${ }^{32}$.

бить і Олена Замура, вказуючи на високий коофіцієнт смертності, причому відмінний в залежності від статі: Замура, О. (2014). «Великий шаленець». Смерть і смертність у Гетьманщині XVIII століття. К., С. 100101.

${ }^{31}$ Арьес, Ф. (1999). Ребенок и семейная жизнь при Старом порядке, С.49. Не всі дослідники поділяють думку Ф.Ар'єса щодо специфічного ставлення до дитинства в добу середньовіччя. Зокрема, Діана Мамичева зауважила: «У відповідності до догматичної точки зору все земне буття знаходиться під владою Бога, який створив людину і повелів їй «плодитися і розмножуватися», тому весь оточуючий світ є втіленням його сакральної волі. Крім того, на землі існували місця, які особливо поважали, де простір і час були дані не у вимірі людського життя, а були зосередженням вічності і безконечності - це храм, Церква, які були втіленням божественної присутності. В сакральному хронотопі Церкви дитина мала абсолютно іншу антропологічну метрику, аніж у повсякденному житті серед людей, оскільки саме тут вона набувала свого дійсного людського обличчя, отримуючи ім'я, свого небесного покровителя і духовних батьків - усе це відбувалося з актом хрещення. Саме хрещення немовлят і дітей старшого віку перетворювало дитину в значиму фігуру, що втілювала ідеал. Тому варто відмітити, що всупереч думці Ф.Ар'єса в християнській культурі дитинство набуло свій хронотоп в сакральному вимірі ще до того, як на нього звернула увагу народна, профанна більшість» (Мамычева, Д. (2013). Детство - метаморфозы культурного взгляда. Таганрог, С. 71). Утім, наступні висновки авторки, зроблені на основі аналізу російського матеріалу і насамперед житійної літератури, практично підтверджують висновки Філіппа Ар'єса про зміну ставлення до дитинства від XIV до XVII ст.: «...Житія XIV-XVII ст. демонструють певну трансформацію давньоруської свідомості, пов'язану з християнським осмисленням сакрального змісту дитинства, в результаті чого семантика останнього наповнилася такими значеннями, як цнотливість, невинність, наївність, святість... Вплив християнської традиції на повсякденні практики сприяв їх поступовій зміні. Поширення християнського образу дитинства як значимого культурного символу сприяло гуманізації відношення до дитини» (Там само, С. 88). Про дискусійність позиції Ф.Арь'єса щодо трактування дитинства в Середньовіччі див.: Clarke, J. (2004). Histories of Childhood, Р. 6-7.

32 Арьес , Ф. (1999). Ребенок и семейная жизнь при Старом порядке, С. 53. На цю трансформацію звертає увагу і В.Маслійчук: Маслійчук, В. (2010). Вік дорослішання: початок повної кримінальної відповідальності в Лівобережній та Слобідській Україні у другій половині XVIII ст., С. 38. 
${ }^{33}$ Еразм Роттердамський. (n.d.). Похвала глупоті (В. Литвинов, Trans.). Retrieved December 15, 2017, from http://www.ae-lib.org.ua/texts/ erasmus_fool_ua.htm\#15.

${ }^{34}$ Детальніше див.:

Sowina, U. (2002). Wdowy i sieroty $\mathrm{w}$ świetle prawa $\mathrm{w}$ miastach Korony w późnym średniowieczu i wczesnej nowożytności. In M. Dąbrowska \& A. Klonder (Eds.), Od narodzin do wieku dojrzatego. Dzieci i młodzież w Polsce (Cz. 1. Od średniowiecza do wieku XVIII). Warszawa, S. 25.

\footnotetext{
${ }^{35}$ Корецкий, М. (Ed.). (1985). Саксонское зерцало. Памятник, комментарии, исследования (Л. Дембо, Trans.). Москва, C. 34 .

36 Там же.
}

I саме це дуже добре видно у кодексах кінця XVI ст. Тут захищається право дитини життя і на маєток, при тому, навіть такої, яка ще не народжена, або яка була народжена, але не вижила. Народжена і охрещена - це вже повноцінна людина 3 подобою Божою і душею. Не дивно, що обгрунтування поблажливого ставлення до дітей знаходимо в творах діячів Відродження. Зокрема Еразм Роттердамський про дітей і дитинство писав: «Всі згодні, що дитинство - найщасливіший і найприємніший вік. Але чим нас приваблюють діти, за що ми їх так любимо, так пестимо? Чому навіть вороги захоплюються ними? А це тому, що вабить усіх до себе принадна глупота, якою розсудлива природа обдарувала дітей. Дещицею насолоди вона скропила важку працю вчителів і зробила їх таким чином лагіднішими до своїх учнів» ${ }^{33}$. Тож жодним чином не виглядає дивною акцептація такого ставлення до дітей у кодексах права, написаних наприкінці XVI ст., які зазнали неоднозначного впливу ідей доби Відродження і Гуманізму.

Відображення дитинства у правових трактатах в різний час відбивало уявлення суспільства про повносправність, відповідальність і вік людини. Ці норми були присутні ще у Саксонському Зерцалі. Саме звідти вони були запозичені до Статуту Яна Ласького. Однак тут не все було однозначним, бо норми міського права у цьому збірнику мали компілятивний характер і базувалися на різних джерелах. Відповідно до Статуту Ласького, опіка над сиротами припинялася після досягнення ними annos pubertatis, що за нормами саксонського права означало 21 рік. Однак в іншому місці Статуту, де за основу було взято Weichbild, зазначалося, що уже в дванадцять років дитина могла визначити, кого бажає собі за опікуна і в окремих випадках виступати за себе у суді: «De puero duodecim annuorum que possit sibi tutorem eligere et pro se in iudicio respondere». Але опікуном можна було стати лише після досягнення 21 року, і тільки 3 того часу можна було виконувати опікунські обов'язки стосовно дружин: «Quando adolescens ad annos pubertatis pervenerint extunc sue uxoris tutor esse potest» ${ }^{34}$. Ця норма суттєво відрізнялася від норми Саксонського Зерцала, відповідно до якої опікуном можна було стати уже по досягненні юнацького віку: «Після досягнення юнацького віку він може бути опікуном своєї дружини або когось іншого, якщо побажає, і навіть виступати за підопічних у поєдинку, хоча він і не повнолітній. Бо оскільки він може себе представляти, то може представляти і підопічних» (ЗП

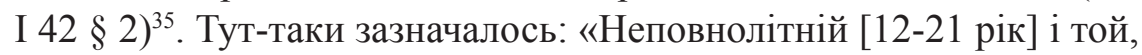
хто досягнув граничного віку [60 років] може мати опікуна, якщо він його потребує, але може його і не мати, якщо не бажає... Після досягнення 21 року чоловік стає повнолітнім... Якщо вік чоловіка невідомий, то він вважається повнолітнім, якщо він уже з бородою і має волосся внизу і під кожною рукою» (ЗП I 42 1). ${ }^{36}$ Останнє цілком відповідало саме середньовічним уявленням про вік людини, бо тоді, коли метричні записи велися нерегулярно, люди рідко абсолютно точно знали дату свого народження, тому уявлення про вік було доволі приблизним і визначалося зовнішніми фізичними ознаками. Навіть у XVI ст. подекуди траплялося, що люди точно не могли визначити свій вік. Певним відголоском давнини було 
${ }^{37}$ Арьес, Ф. Ребенок и семейная жизнь при старом порядке, С. 29-30.
${ }^{38}$ Іваницький-Василенко, С. Закони про опіку над недолітками у джерелах Магдебурзького права Західної Русі й Гетьманщини, С. 72.

${ }^{39}$ Szczerbicz, P. (1581). Speculum Saxonum albo Prawo Saskie y Maydeburskie, porządkiem obiecadla $\mathrm{z}$ łacińskich y niemieckich exemplarzow zebrine, a na polski język z pilnośćią y wiernie przełożone. Lwów, S. 198. уявлення про пристойність, що побутувало в XVI ст., відповідно до якого не варто було називати однозначно кількість своїх років, застосовуючи натомість ухильні формулювання, причому поширене воно було навіть серед тих, хто здобув освіту і пройшов школу, де уже була розвинута звичка до точності, і діти уже знали свій вік. За Ф.Ар'єсом, «навіть коли навички особистої хронології поширилися повсюдно, вони не стали позитивним знанням і не розвіяли попередній морок навколо віку, який ще певний час зберігався в добрих манерах» ${ }^{37}$. При тому станом на XVI ст. питання про вік для людей уже не було проблемним, і воно чітко співвідносилося 3 календарем.

На плутанину і неоднозначність у трактуванні періоду закінчення опіки, а відтак, і дитинства, вказував Сергій Іваницький-Василенко: «Пізніші досліди виявили, що доба до 21 року поділялася в саксонському праві на дві частини: перша до 13 року, коли кінчалася обов'язкова опіка, i друга до 21 року, коли чоловік міг мати опікуна, якщо в тому була потреба. 3 наших джерел підтвердження цьому ми знаходимо тільки в глосі. Так, з глоси до S.S. довідуємось, що pubertas починається, за саксонським правом, у 12 років, що духівниці писати можна було лише по 14 році, маєтки здобути по 18 р., i, нарешті, справувати опіки лише по 21 року. Глоса до иншого атр. S.S. (I, 42) повторює, що pubertas починається по 12 p., anni discretionis по 21 року. Проте в глосі до I.M. (26) ми знаходимо вже инший реченець: глосатор пише, що в саксонському праві починається pubertas i кінчається опіка для хлопця в 14 років, а для дівчат в 13 років, 3 того-ж-таки часу людина дістає право розпоряджатися своїм маєтком, а опікуна може собі обрати, як схоче мати його взагалі, - це вже новий принцип, не знати, звідки взятий, бо й у Юстиніяновому праві реченець цей був инший: 14 i 12 років. До цієї плутанини Яскерова glossa marginalis докидає, що глосу Iuris Municipaleis треба вважати за perplexa, бо справді pubertas починається по 14 i 13 роках, a anni discretionis по 21 року (I.M., 26). Після сказаного не дивно, що в Гроїцького і Щербича немає одностайності в тім, коли кінчається опіка: адже перед ними був текст S.S. і дві глоси, і кожне з них держалось в цьому питанні свого погляду» ${ }^{38}$.

Для людей середньовіччя, які мислили предметно, як зазначалось вище, важливими були речі намацальні. Тож не дивно, що уявлення про досягнення людиною повноліття опиралося не так на формальні кількість років, як на реальні зовнішні фізіологічні ознаки, але з часом таке «візуальне» визначення віку людини відходить на задній план. Це зауважив також Павло Щербич: «Але цей звичай імператорське право відкинуло, яке так каже: Дорослішання перед тим не лише кількістю років, але також і тілом чоловіка має визначатися. Але оскільки це буває проти соромливості, тому встановлюємо, щоб дорослість у чоловіків після чотирнадцяти років наставала, а у жінок у дванадцять років аби кожна дорослою вважалася. ... Коли про чиїсь роки є сумнів, тоді мають оглядати частини тіла. Але якби про них була якась достовірна відомість, тоді того огляду не потрібно» ${ }^{39}$. Еволюція поглядів на дитинство в цьому контексті від XIV до кінця XVI ст. була очевидною. 
${ }^{40}$ Гроїцький виділяє окремо опіку над неповносправними, до яких крім інших зараховували глухих і німих. Якщо опікуна над сиротами називали tutor, то опікуна над неповносправними називали curator. «Польською його радше можна назвати розпорядником, а не опікуном». У даному випадку кураторство мало тривати стільки, скільки було необхідно, але куратор на своїй посаді міг бути лише двадцять п'ять років (Groicki, B. Tytuły prawa majdeburskiego, S. 195).

${ }^{41}$ Ibidem, S. 197.

${ }^{42}$ Groicki, B. (1958). Oborona sierot i wdów. Warszawa, S. 228. Відповідно до литовського права, де опіці було присвячено чимало уваги, опікун також повинен був по закінченні опіки повернути маєтки сиротам без жодних збитків. В іншому випадку вони мали право подавати до суду, але щоб час подання не перевищував земської позовної давності, що складала 10 років. Зокрема, у Литовському Статуті 1566 р. у шостому розділі «Про опіку» зазначалося: «...А коли діти до розумних і дорослих літ дійдуть, опікуни повинні будуть ті всі маєтності дітей, як нерухомі, так і рухомі, і всякі доходи з маєтків їх, збори грошові i медові й інші всякі, які за весь час опіки своєї зберуть, їм віддати, і лічбу повну вчинивши 3 усього, усправедливитися» (Арт. 4); «А коли б опікун дітей за що-небудь був позваний, за те опікун не повинен у суді відповідати, окрім тих причин, які нижче описані, бо опікун не повинен дітям нічого втратити, і якби опікун за їх неповноліття щось втратив; чим би

дітям кривда діялася, тоді вони, досягнувши повноліття, можуть про ті кривди свої заявити і через суд того добиватися, тільки б давності земської не пропустити» (Арт. 6) ( Ківалов, С. \& Музиченко, П. \& Паньков, A. (Eds.). (2003). Статути Великого князівства Литовського у 3-х томах. Т. II. Статут Великого князівства Литовського 1566 року. Одеса, С. 336-337)

${ }^{43}$ Szczerbicz, P. Speculum Saxonum albo Prawo Saskie y Maydeburskie.., S. 197.

44 Для жінок досягнення 25 років теж було певним рубежем - саме 3 досягненням цього віку дівчину не можна було позбавити спадку, навіть якщо вона вийшла заміж без згоди на те батьків. Бо саме батьки вважалися винними, що вона дожила у дівках до цього віку (Groicki, B. Tytuły prawa majdeburskiego, S. 22; Groicki, B. Oborona sierot i wdów, S. 93-94).
Для Бартоломея Гроїцького також питання про досягнення дитиною віку, коли наступає правова відповідальність, пов'язане із питанням часу, до якого дитині необхідний опікун: «Опіка триває до досягнення сиротою чотирнадцяти років для хлопців. А якщо $є$ дівчина, тоді до тринадцяти років... ${ }^{40}$. Саме 3 чотирнадцяти років сирота набуває право вимагати від уряду іншого опікуна чи куратора $^{41}$. Щоправда, оскільки траплялися випадки, коли опікун 3 тих чи інших міркувань не хотів повертати підопічному його маєтки і намагався утриматися при своїх функціях, то право передбачало можливості для дитини вийти з такої ситуації і звільнитися від опіки. Для цього дитині чи молодій людині необхідно було довести, що має щонайменше чотирнадцять років і може звільнитися від опіки: «Сирота, якщо хоче від опіки звільнитися, коли досягає молодих років або можливості народження, такі роки називаються ad annos puberitatis, 14 років, або років розторопності, ad annos pertectae discretionis, 21 рік, а хоче собі вже бути вільним, не під владою опікуна, повинен довести вік. А докази такі мають бути: прийти до уряду з двома кревними по батькові, cum duobus agnatis, i з двома кревними по матерi, cum duobus cognatis, які визнають роки даного сироти. Після такого визнання роки йому будуть присуджені, і тоді вже буде дозволено тому сироті управляти і керувати своїми маєтками, незважаючи на спротив опікуна, будучи при доброму здоров $і$ і. І буде йому дозволено обрати собі іншого опікуна, до часу, до якого хотів би. А той перший опікун, маєтки, які мав під своєю опікою, зобов’ язаний буде йому віддати» ${ }^{42}$.

Дещо інакше, детальніше, описує повноліття Павло Щербич. У своєму трактаті він виділяє окремі етапи, коли дитина набуває права вчиняти ті чи інші дії. Таких періодів він виокремлює чотири. Зокрема, посилаючись на саксонське право, він зазначає: «Перший, коли хтось доростає молодості, що буває в тринадцять років + i шість тижнів + за ленним правом, а за саксонським в дванадцять років. Другий, коли хто до років розумних приходить, тобто чотирнадцяти років, після чого тестамент може укласти. Третій, коли кому вісімнадцять років буде, після чого може [свою власність відокремити] + в німецькому стоїть. Слугу невільного може відпустити, +чого раніше зробити не може. Четвертий, коли вже хтось до двадцять і одного року дійде, тоді вже повні роки має + а відповідно до імператорського права, аж двадцять і п’ять років + i тоді вже опікуном може бути» ${ }^{43}$ Варто згадати, що саме за міським правом вважалося, що від 25 років чоловік ${ }^{44}$ може бути обраний до міської ради: «Для добра міста в раду мають бути обрані люди добрі, мудрі, що досягли віку принаймні двадцяти п’яти 
${ }^{45}$ Groicki, B. (1953). Porządek sądów i spraw miejskich prawa majdeburskiego w Koronie Polskiej. Warszawa, S. 29.

${ }^{46}$ Ibidem, S. 28.

47 (1623). Prawa

Chelmienskiego poprawionego y z lacinskiego ięzyka na polski przetlumaczonego, xiąg piecioro ku pospolitemu pozytkowi przez Pawla Kuszewica z Chelmna. Poznań, S. 91.

${ }^{48}$ Korczak-Siedlecka, J. (2014). Model wychowania dziewcząt w szesnastowiecznej Polsce. In Odrodzenie i Reformacja w Polsce. T. LVIII, S. 52. Бартоломей Гроїцький ставить жінок в один ряд з глухими, німими, сліпими, лунатиками, які, як і викляті чи відступники від християнської віри, не можуть бути суддями. Правник зауважує, що таке обмеження стосується жінок, які не можуть претендувати також на інші уряди, бо вони не здатні відповідти за свої дії, а відтак самі потребують опікуна (Groicki, B. Porządek sądów i spraw miejskich prawa majdeburskiego w Koronie Polskiej, S. 28).

49 Детальніше див.: KorczakSiedlecka, J. Model wychowania dziewcząt w szesnastowiecznej Polsce, S. 49-71.

${ }^{50}$ Статути Великого князівства Литовського у 3-х тт. Т. II, С. 133 (Розділ VI, арт. 1); у перекладі цього артикулу статуту допущено помилку і вказано для чоловіквів вік 18 років (Там само, С. 335).

${ }^{51}$ Статути Великого князівства Литовського у 3-х тт. Т. III, С. 525 (Розділ VI, арт. 1).

52 Ворончук, I. Інститут опіки: правові норми та повсякденні практики на Волині ранньомодерної доби, С. 138.

${ }^{53}$ Статути Великого князівства Литовського у 3-х тт. Т. I, С. 239 (Розділ V, арт. 14). років...» ${ }^{45}$. Натомість суддею, чи то лавником, він міг стати уже 3 21 року життя ${ }^{46}$.

При тому окремо зазначалося, що якщо дитина досягала двадцяти одного року, то не мала потреби в опікуні, бо сама могла розпоряджатися власним майном. Але це стосувалося лише чоловічої статті, бо дівчата і жінки потребували опікуна і після досягнення даного віку. I це для Павла Кушевича $\epsilon$ «річ явна і ясна» ${ }^{47}$. Варто зауважити, що стать дитини у правових джерелах розрізняли лише із досягненням annos pubertatis, який був різний для представників різних статей, бо від цього часу і хлопці, і дівчата могли обирати собі опікуна, з тією лише різницею, що дівчата не могли повністю від нього відмовитися. У суспільній практиці виглядало так, що дівчата ніколи не ставали дорослими, бо не були самостійними, вони переходили від опіки батька до опіки чоловіка ${ }^{48}$. Але хоч у правових приписах стосовно дитинства немає гендерних відмінностей, та вже на практиці дівчатка і хлопці виховувалися по різному, виходячи із тих уявлень про гендерні ролі, які були пануючими в суспільстві певного історичного періоду ${ }^{49}$.

У поглядах на дитинство чітко прослідковується відмінність між німецьким міським і литовським правом. I хоч в останньому відбувалася еволюція від Статуту до Статуту, та різниця в порівнянні з німецьким правом була збережена. У литовських статутах питання про межу повноліття прописана в розділах про опіку. Зокрема в 1529 р. зазначалось: «Уставуем, абы по смерти родичов детем, лет недорослым, шкоды и розпрошенья маетностей их як лежачих, так и рухомых, не было; с тое причины таковые дети лет недорослые мают быти под справою и опатрностью опекунов от родичов назначеных, або теж придатных до лет зуполных, а лета мыжчизне мають быти зуполные семнадцать, а девка петнадцать лет» ${ }^{50}$. Однак, за Статутом 1588 р. ця межа була змінена на 18 років для чоловіків, і 13 для дівчат: «Уставуем, абы по смерти родичов детем, лет недорослым, шкоды и распрошенья маетности их яко лежачих, так и рухомых, не было, с тое причины таковые дети, лет недорослые, мають быти под справою и опатрностью опекунов, от родичов назначеных албо прирожоных, албо приданых до лет зуполных. А лета мужчизна маеть мети зупольные осмнадцать лет, а девка тринадцать лет» ${ }^{51}$. Щоправда, Ірина Ворончук зауважила 3 цього приводу, що «в українських землях віковий ценз повноліття дівчат не дотримувався: їх часто видавали заміж до досягнення 15-річного віку» ${ }^{52}$. За литовськими статутами неповнолітні діти також не могли укладати тестаменти, але оскільки тут межа повноліття була іншою, то і укладання тестаменту дозволялося не 3 чотирнадцяти років, а 3 часу визначеного повноліття ${ }^{53}$.

Можна припустити, що вищий віковий ценз для хлопців в питанні досягнення повноліття за литовським правом, яке в основі своїй було все ж здебільшого правом земським, був пов'язаний із правом на успадкування землі та з військовою справою. Міщани ні одного, ні другого відповідно до права по спадку не мали. Така відмінність між ленним і земським правом відобразилась уже у Саксонському Зерцалі, де чітко зазначалось, що за ленним правом хлопець, який досяг лише юнацького віку (13 років), зобов’ язаний 
${ }^{54}$ Саксонское зерцало. Памятник, комментарии, исследования, С. 28 (ЗП I 23 §).

55 Детальніше див.: Bardach, J. (1999). Statuty litewskie a prawo rzymskie. In Axer, J. (Ed.). Lacina w Polsce. Zeszyty Naukowe, Z. 7-9; (1999). Pomniki prawa doby Renesansu w Europie ŚrodkowoWsxhodniej. Warszawa, S. 11-15; Godek, S. (2013). Prawo rzymskie w Polsce przedrozbiorowej w świetle aktualnych badań. Zeszyty Prawnicze. Nr. 13/3. 2013, S. 55-57.

${ }^{56}$ Prawa Chelmienskiego poprawionego y z lacinskiego ięzyka na polski przetlumaczonego, xiąg piecioro ku pospolitemu pozytkowi przez Pawla Kuszewica z Chelmna, S. 174.

${ }^{57}$ Groicki, B. (1954). Artykuły prawa majdeburskiego, które zowią Speculum Saxonum z łacińskiego jȩzyka na polski przełożone i znowu drukowane roku pańskiego 1629. Warszawa, S. 50 .

${ }^{58}$ Клервоский, Б. (2009). О благодати и свободном выборе. У Б. Клервоский (Author) \& Ю Ромашев (Ed.), Трактать. СПб., С. 147. мати опікуна, який би заступав його у маєтку і служив би пану, як мав служити його підопічний ${ }^{54}$. Однак, прямого впливу на Литовські статути в цьому питанні саксонське право вочевидь не мало. Норми радше за все диктувалися практичними потребами і міркуваннями доцільності. Утім, питання впливу німецького і римського права на право литовське і нині залишається відкритим ${ }^{55}$.

Німецьке міське право захищало дітей від надто суворих покарань, насамперед від страти. Злочин, який вчинявся дітьми, мав бути відшкодований матеріально, але це стосувалося лише тих, хто не досягнув «літ розторопних»: «Поки хто не має більше аніж 15 років, і украв би щось, тоді горло не тратить. Але опікун 3 його маєтків, тим, кому украдена річ належала, нехай відшкодує. А якби не було чим нагородити і заплатити, тоді його відшмагати» ${ }^{56}$. Схожі пасажі читаємо і в Гроїцького: «А однак дитина, яка вже близько до літ розторопних, може бути покарана за великий злочин; але якщо б була ще ближча до дитячих років, ніж до років визначених, тобто до чотирнадцяти років, тоді не має бути карана на горло, але опікун має за неї заплатити. Дитина і божевільний насильства учинити не можуть, бо насильства не може ніхто вчинити, крім тих, хто його чинить обдумано і добровільно, а діти і божевільні таких здібностей не мають. I відтак на горло не мають бути покарані, тільки шкоди, які вони чинять, мають бути відшкодовані. Speculum Saxonum libro 2 articulo 65 et libro 3 articulo 3. Et Iure Municipali articulo $38{ }^{57}$.

Вважалося, що до досягнення відповідного віку, дитина була істотою несвідомою, тому свідомо вчиняти злочини не могла. А за неусвідомлені провини неприпустимо було карати на смерть (як наприклад людину, що була не сповна розуму). Обгрунтування цього було дано ще в попередні епохи, зокрема Бернардом Клервоським: «Там, де немає свободи, немає і воздаяння, а тому немає і суду (за винятком, звичайно, первородного гріха, який, як відомо, має іншу основу). У всіх же інших випадках, де відсутня свобода, узгоджена з волею, безсумнівно, немає ні воздаяння, ні суду... Воля такою ж мірою не може позбутися свободи, як і самої себе. Якби людина могла взагалі нічого не бажати, або бажати, але не по своїй волі, воля могла би бути позбавлена свободи. Тому душевно хворим, дітям, а також людям, які сплять, не ставлять в провину ні добро, ні зло, оскільки, не володіючи розумом, вони, очевидно, не можуть скористатися своєю волею, а звідси і судженням, притаманним волі. Оскільки воля абсолютно вільна, то за справедливістю вона судиться тільки самою собою» ${ }^{58}$.

Таке ставлення до дитини, як до особи несвідомої, характерне було насамперед для середньовіччя. Зокрема, в одній із тогочасних притч читаємо: «Валерій розповідає про п’ятирічного хлопчика, який щодня виходив над море. Побачив це дельфін, почав гратися 3 хлопцем і возити його на спині, а той дельфінові хліба носив і так п'ять чи то десять літ його живив. Трапилося одного дня, що хлопець, як звичайно, вийшов над море 3 хлібом, та дельфін усе не з'являвся. Тим часом наринуло море, змило хлопця і він потонув. Коли приплив дельфін і знайшов хлопчину мертвого, то від великого жалю впав біля нього і помер. Найдорожчі, тим хлопцем можна вважати кожного доброго християнина, який щодня 
${ }^{59}$ Паранько, Р. (transl.) (2014). Діяння римські. Християнські притчі Середньовіччя. Львів, C. 357.

${ }^{60}$ Цит. за: Делюмо, Ж. (2003). Грех и страх: Формирование чувства вины и цивилизации Запада (XIII-XVIII вв.). Екатеринбург, С. 619.

${ }^{61}$ Groicki, B. Artykuły prawa majdeburskiego, które zowią Speculum Saxonum z łacińskiego jȩzyka na polski przełożone i znowu drukowane roku pańskiego 1629, S. 71.

${ }^{62}$ Szczerbic, P. (2011). Ius Municipale, to jest prawo miejskie majdeburskie, nowo $\mathrm{z}$ łacińskiego i z niemieckiego na polski jȩzyk z pilnością i wiernie przełożone. Kraków, Wyd. G.M.Kowalski, S. 240.

${ }^{63}$ Ibidem, S. 238; Szczerbicz, P. Speculum Saxonum albo Prawo Saskie y Maydeburskie..., S. 27.

${ }^{64}$ Щоправда, тут були передбачені винятки: «Однак бувають такі проступки, за які навіть перелічені особи не бувають звільнені від тортур, як от виступ проти короля, проти громадської справи, що латинники називають crimen laesae Majestatis, тобто, якщо хтось щось таке допустить, що б було проти короля і його безпеки, коли проти скаже або містові щось нашкодить, коли до неприятеля схилиться, коли неприятелеві зброєю, грошима, порадою і яким-небуть іншим способом проти свого пана допоможе, коли підданих землі до того приведе, аби були проти короля, коли розбрат в місті чинить, щоб найвищу особу вбити, та інше тому подібне. Також не робить нікого вільним від тортур здача і зрада своєї Вітчизни, здача неприятелям міст і замків, хто би не був таким» (Groicki, B. Porządek sądów i spraw miejskich prawa majdeburskiego w Koronie Polskiej, S. 195). має ходити понад морем, тобто понад світом, а не в світі, сіючи діла милосердя. Отож і праотець Адам був тим хлопчиком, бо до того не згрішив, вів життя в чистоті понад світом, у земному раю, де споглядав Бога. Дельфін - це Бог, який сотворив Адама і своєю благодаттю переніс його 3 поля Дамаського до раю. Хлопець Адам помер, коли всупереч Божій заповіді з’їв плоду і поринув у морські хвилі, тобто в злидні сього світу, згідно з книгою Буття: «В поті лиця твого...» і далі. Але Дельфін, себто Бог, так полюбив його, що з любові до нього зійшов з небес і за його рід вмер на хресті» ${ }^{59}$. Дитя несвідоме, і тим миле Богові.

Дитя безгрішне, i лише тоді, коли минає дитинство, людина отримує можливість грішити і відповідати за свої вчинки. Саме тому норми міського права не передбачали жорстокого пакарання для дітей, оскільки останні не були свідомими своїх вчинків.

До речі, саме в період, коли дітей стали трактувати як особистостей $з$ душею і подобою Божою, змінюється ставлення до дитячої смерті. Саме через таку невинність, яка притаманна була дітям, вважалося, що душі померлих дітей потрапляють до раю. У своїй проповіді до дня невинно убієнних дітей французький єпископ, поет і богослов Антуан Годо (1605-1672) дивувався скорботі батьків, чиї діти померли, оскільки на його думку, така рання кончина дає цим дітям, особливо немовлятам, шанс на вічне спасіння, оскільки вони, померши, зберегли свою невинність, дану їм при хрещенні. «I так, щасливі ті діти, котрі помирають перед тим, як впадуть у те нещастя [смертний гріх]! Щасливі ті, батьки і матері, котрі втратили їх у такому віці. Отже, не варто впадати у скорботу, як ви це робите, плакати, нарікати, входити у відчай, богохульствувати, звинувачувати провидіння, що ви втратили їх немовлятами чи дітьми. Ви не відаєте, що творите» ${ }^{60}$. Одначе зрозуміло, що навіть у такому сприйнятті дитинства відображено уявлення про дитину як істоту одухотворену, і поступово особливе, почасти трепетне ставлення до дитинства тільки зростало.

В цьому контексті зрозумілою стає норма, відповідно до якої не можна було стратити вагітну жінку, адже то була страта і дитини, яка вважалась невинною: «Покарання на горло або на здоров’я має бути відтерміновано таким особам: Вагітній жінці, аж до пологів. Дитині, яка ще відповідного віку не досягнула а опікуна не має, тоді відкладають до другого суду, аби опікуна мала. Шаленцю, щоб дізнатися, чи з шаленства це вчинив, чи з іншої причини. Speculum Saxonum libro 3 articulo 3 et libro 2 articulo 55» ${ }^{61}$. Павло Щербич підкреслює, що навіть за вбивство, підпал, злодійство чи інші злочини, жінка не може бути покарана на горло під час вагітності, бо у випадку іiі страти, загине і дитина, яку вона носить. А ненароджене немовля ні в чому не винне, i це було б проти справедливості щодо нього, бо діти не мають відповідати за проступки чи злочини своїх батьків. Тому у випадку, коли жінка вчинила б злочин, який би заслуговував на смертну кару, виконання вироку має бути відкладено на час після пологів ${ }^{62}$.

Через вагітність жінку також не можна було покарати більше, аніж «на шкірі чи на волоссі» ${ }^{63}$. Ї̈і, як і дитину до чотирнадцяти років чи стару людину (після сімдесяти років), не можна було віддати на тортури ${ }^{64}$. Вагітна мала понести такого роду покарання тільки 
${ }^{65}$ Groicki, B. Tytuły prawa majdeburskiego, S. 88-89. 3a Литовським Статутом також передбачалося суворе покарання за шкоду, заподіяну вагітній жінці, а якщо ж вагітна жінка і іiі дитина чи плід померли в результаті нанесеної матері шкоди, то ця дія мала каратися смертю кривдника (Див.: Статути Великого князівства Литовського у 3-х томах. Т. III, С. 276-277 (Розділ 11, арт. 15)). Щоправда, як показав у своєму дослідженні Ігор Сердюк на прикладі Гетьманщини, ця норма не завжди виконувалася (Сердюк, I. Дитина і дитинство в Гетьманщині XVIII ст., С. 5760).

${ }^{66}$ Szczerbic, P. Ius Municipale..., S. 239.

${ }^{67}$ Groicki, B. Artykuły prawa majdeburskiego, które zowią Speculum Saxonum z łacińskiego jȩzyka na polski przełożone..., S. 50.

${ }^{68}$ Modrzewski, A. F. (n.d.) O poprawie Rzeczypospolitej. Retrieved December 15, 2017, from https://wolnelektury.pl/ katalog/lektura/o-poprawierzeczypospolitej.html\#footnoteidm 140071968

${ }^{69}$ Groicki, B. Artykuły prawa majdeburskiego, które zowią Speculum Saxonum z łacińskiego języka na polski przełożone.., S. 51.

${ }^{70}$ Prawa Chelmienskiego poprawionego y z

lacinskiego iȩzyka na polski przetlumaczonego, xiąg piecioro ku pospolitemu pozytkowi przez Pawla Kuszewica z Chelmna, S. 89.

${ }^{71}$ Гроїцький окремо підкреслює, що опіка над дітьми відрізняється від опіки чоловіка над власною жінкою, бо у другому випадку чоловік володіє рухомим майном жінки на праві власності, і не мають рації ті, які вважають, що як належить опікунові, чоловік нічого 3 майна жінки не може брати (Groicki, B. Tytuły prawa majdeburskiego, S. 196).

${ }^{72}$ Groicki, B. Tytuły prawa majdeburskiego, S. 196, 197. після народження дитина. Окрім того, до пологів їі опікуном, як і розпорядником маєтків, мав бути найближчий кревний померлого чоловіка, який має дбати і про матір, i про дитину, і про майно 65 . Павло Щербич однак зауважив, що такий родич може бути опікуном лише дитини, навіть ще ненародженої, але для матері він має бути розпорядником і захисником маєтків ${ }^{66}$.

Дитина захищалась законом, аж до тої міри, що вбивство дитини розглядалось на рівні із вбивством дорослої людини, що теж свідчить про еволюцію ставлення до дитинства і дітей. За Гроїцьким: «Дитина, доки років розторопних не дійде, за жодну провину на горло скарана бути не може. Якщо когось убила або скалічила, тоді опікун з їі майна повинен це відшкодувати і заплатити, також і шкоди, які б дитина учинила, якби провина їі була доведена. Якби хто дитину вбив, заплатити за неї має, як за вбивство. Якщо також хтось чужу дитину мітлою або за волосся покарав, якщо тільки присягне, що то вчинив за провину їі, за те не відповідатиме...» ${ }^{67}$. Видно, що на відміну від убивства, рукоприкладство за провини, які були вчинені дитиною, розглядалося як річ цілком нормальна i буденна. Такою була і суспільна думка того часу. Зокрема, відомий польський політичний і релігійний діяч XVI ст. Анджей Фрич Моджевський, описуючи принципи виховання дітей, зауважував: «Нехай тоді того ретельно пильнують, аби хлоп'ята і дівчата перших молодих років своїх не проводили в ледарстві; нехай стараються, аби завжди щось робили..., лінивство належить словом карати, а якщо від обов'язків своїх далеко відступили, тоді і покарання різками буде слушним. Бо Соломон, мудрий король, казав: не віддаляй від дитини своєї покарання; якщо її вдариш різкою, не помре; ти його б'єш, а душу з пекла виганяєш» ${ }^{6}$.

Однак, безперечно, тілесне покарання мало бути поміркованим і не нести загрози для життя дитини.

Якщо ж убивство дитини було випадковим, то воно могло бути відшкодоване грішми: «Якщо б хто посадив дитину на коня твердоустого, який би не дав себе затримати, а через те він би дитину вбив, пан того коня має заплатити у відповідності до права, якщо хоче свого коня мати. Speculum Saxonum libro 2 articulo 40. Et Iure Municipali articulo 38» ${ }^{69}$.

Закон особливо пильнував матеріальні інтереси дітей. Відповідно до норм хелмінського права, опікун не міг усунути сироту 3 його маєтків, грунтів чи від нерухомості без згоди на те міської ради $^{70}$. Опікун нічого не міг собі присвоїти з маєтків сироти ${ }^{71}$, мав докладати чималої праці і часом міг наражатися на певні небезпеки, бо всяке його управління мало бути лише на користь сироті 72 . Діти не мали відповідати і за борги, які були у їхніх батьків, але лише в тому разі, коли не успадкували достатньо майна, яке дало б їм можливість такі борги виплатити: «Діти, коли батько помре, не повинні жодних боргів платити за померлого батька або за матір, якщо їх батьки осиротили, і якщо після них жодного спадку не беруть; а якщо візьмуть, тоді повинні будуть борги платити. 
${ }^{73}$ Groicki, B. Artykuły prawa majdeburskiego, które zowią Speculum Saxonum..., S. 50-51.

${ }^{74}$ Groicki, B. Tytuły prawa majdeburskiego, S. 196.

${ }^{75}$ Prawa Chelmienskiego poprawionego y z lacinskiego ięzyka na polski przetlumaczonego, xiąg piecioro ku pospolitemu pozytkowi przez Pawla Kuszewica z Chelmna, S. 69.

${ }^{76}$ Groicki, B. Tytuły prawa majdeburskiego, S. 182.

${ }^{77}$ Ibidem, S. 88.

${ }^{78}$ Szczerbic, P. Ius Municipale..., S. 239; Szczerbicz, P. Speculum Saxonum albo Prawo Saskie y Maydeburskie..., S. 24-25.
Speculum Saxonum libro 3 articulo 10. Et libro 1 articulo 6» ${ }^{73}$. Taкож заборонялося керувати маєтками сироти через довірених осіб, щоб завжди було з кого спитати у випадку розтрат. Якщо ж сироти зазнавали матеріальних втрат через нещасні випадки чи якісь інші катаклізми, то опікун не мав за це відповідати, але у разі, якби міг цьому перешкодити чи попередити, але цього не зробив, то мав із власних маєтків сироті відшкодувати. Крім того, обов'язки опікуна не переходили на його дітей ${ }^{74}$. При тому закон пильнував інтереси всіх дітей і убезпечував їх від свавілля одне одного. Зокрема, відповідно до норм хелмінського права, отримавши по батькові або матері спадок, діти могли розділити між собою майно, але ніхто 3 них зосібна не міг нічого нікому віддати чи подарувати без згоди усіх інших ${ }^{75}$.

Правом були захищені інтереси і тих дітей, які на момент смерті батька ще не народилися. Вони так само, як і всі інші діти, мали право на спадок по батькові, i батько мав згадати їх у своєму тестаменті. Але на відміну від інших дітей, вони не могли бути позбавлені спадку, оскільки ненароджені не могли спричинитися до того, щоб їх можна було в чомусь звинуватити. Інших дітей батько міг позбавити спадку, вказавши в тестаменті вагому причину, через яку так вчиняє. А взагалі ж міське магдебурзьке право встановлювало: «Батько, який укладає тестамент і має різних дітей - одних під своєю владою, інших уже відправлених - повинен всіх відзначити в тестаменті, якщо одним призначає спадок, а інших його позбавляє... I того теж, який би ще по смерті його мав народитися (називається postumus). I то тому повинен всіх відзначити, щоб між ними навколо його маєтків сварка не виникала, або також щоб тестамент у своїй силі відповідно до права діяв. Бо якщо якого сина упустив, погано уклав тестамент, то той, який почувається скривдженим, може оскаржити тестамент протягом п'яти років ${ }^{76}$. Окрім того, вагітна жінка не могла бути вигнана 3 маєтку померлого чоловіка, оскільки носила під грудьми майбутнього спадкоємця по батькові. За старими глосами, як зазначав Гроїцький, жінку не можна було з маєтку вигнати допоки дитину грудьми годувала, i то не інакше, як з вагомих причин ${ }^{77}$. Щербич пояснює, що вагітна жінка не може бути вигнана з маєтків чоловіка, бо навіть якби могла, то плід, який вона носить, через те, що є майбутнім дідичем маєтків, з них усунутий бути не може. А оскільки плід живиться і росте від матері, то вона має отримати достатнє утримання в цих маєтках колишнього чоловіка ${ }^{78} .3$ цього видно, що про майбутню дитину думали, як про особистість, яка має не лише право на життя, але і на спадок.

Цікаво, що за дітьми визнається право на успадкування навіть у тих випадках, коли дитина не вижила. Кодекси XVI ст. знають таку процедуру народження як кесарів розтин, хоч і не знають такої термінології. Відповідно до даної термінології - мова про «дітей із живота випоротих». Очевидно такий спосіб пологів був особливо небезпечним, тому виникла необхідність обумовити майнову ситуацію у випадку, коли діти, народжені в такий спосіб, не виживали. Хелмінське право передбачало: «Коли дитина при тяжких пологах, з живота материнського буде випорота, яку 
${ }^{79}$ Prawa Chelmienskiego poprawionego y z

lacinskiego ięzyka na polski przetlumaczonego, xiąg piecioro ku pospolitemu pozytkowi przez Pawla Kuszewica z Chelmna, S. 75 .

${ }^{80}$ Szczerbic, P. Ius Municipale..., S. 238.

${ }^{81}$ Groicki, B. Tytuły prawa majdeburskiego, S. 87.

${ }^{82}$ Мамычева, Д. Детство - метаморфозы культурного взгляда, С. 77.

${ }^{83}$ Groicki, B. Oborona sierot i wdów, S. 244.

${ }^{84}$ Szczerbicz, P. Speculum Saxonum..., S. 27. жінка чи баба візьме на лоно і охрестить іiі, а жінка, яка на той час при тій справі особисто була, бачила, що дитина рухала устами i двічі позіхнула, а потім померла, тоді має така дитина вважатися за правдиво народжену, так що право наступило на суксесію материнську, і передало їі на свою суксесію» ${ }^{79}$. Подібні пасажі були в трактаті Павла Щербича ${ }^{80}$ та Бартоломея Гроїцького ${ }^{81}$.

Зрозуміло, що це положення захищало право як матері, так i новонароджених дітей. Для легітимації народження надзвичайно важливим був обряд хрещення, який в силу обставин міг бути максимально спрощеним. Саме цей обряд, як і надання імені, був символом втримання дитини у світі людей. Діана Мамичева зауважила: «Широко побутувало уявлення, що якщо довго не хрестити дитину, то нечиста сила підмінить їі своїм дитинчам; або якщо повитуха забуде ім’я дитини, то остання помре. За часом надання імені збігалося з обрядом хрещення, з якого, власне, і починалася людська доля немовляти, про що говорить і приказка: «Поки не хрещений, його не цілують: нехрещена дитина - чортеня». До хрещення дитина вважається нечистою: іiї не клали в колиску, не надягали сорочку, тільки пеленали, іноді навіть не допускали до грудей матері. Після отримання імені і хрещення, дитина набувала нової якості: ставала об’єктом соціокультурного простору, істотою, яка могла бути пізнаною і пізнавати. Якщо дитина помирала нехрещеною, ïi, як нечисту, ховали не на кладовищі, а за огорожею, в болоті, якщо в хаті, то закопували під поріг або в красному куті. Відповідно до міфологічних уявлень, діти, що померли до хрещення, перетворювалися в русалок або ж потрапляли до нечистої сили, тобто поверталися туди, звідки з'явилися» ${ }^{82}$.

До ненародженої дитини ставилися як до реальної, бо ще ненароджена дитина не тільки мала мати опікуна, але відповідно до права, в ситуації, якщо дитина помре при народжені, опікун має вчинити реєстр маєтків для спадкоємців цієї дитини, і такий обрахунок мав бути скріплений присягою опікуна ${ }^{83}$.

Інтереси дітей певною мірою були захищені навіть у тому випадку, коли чоловік одружувався з жінкою, не знаючи, що не може цього робити згідно з приписами права, і був потім з нею розлучений церквою. Якщо в такому шлюбі були діти (ті, які народилися в шлюбі, i ті, які були ще не народженими, але вже зачатими на момент розлучення батьків), то за ними зберігалися всі права, так, якби вони були народжені у звичайній сім’”84.

Щоправда, мова могла йти лише про тих не народжених на момент смерті батька дітей, яких визнали за «дітей правдивого ложа». Це теж обумовлювалось правом. Якщо у найближчих родичів померлого чоловіка виникли сумніви щодо вагітності жінки на час його смерті, чи щодо того, чи його дитину носить жінка, то суперечка мала бути вирішена не тільки і не стільки присягою жінки чи інших зацікавлених осіб, але радше певними підрахунками: «Якщо день народження дитини припаде на час понад десять місяців і два дні (протягом якого зазвичай матері плід в животі своєму носять, почавши цей час відраховувати від дев'ятого дня від смерті батька), тоді цей плід не є від померлого чоловіка, тоді така дитина від маєтків покійника нічого не матиме, і тоді справж- 
${ }^{85}$ Groicki, B. Tytuły prawa majdeburskiego, S. 88.

${ }^{86}$ Szczerbic, P. Ius Municipale..., S. 239 .

${ }^{87}$ Ibidem, S. 240.

${ }^{88}$ Ibidem, S. 239.

${ }^{89}$ Prawa Chelmienskiego poprawionego y z

lacinskiego ięzyka na polski przetlumaczonego, xiąg piecioro ku pospolitemu pozytkowi przez Pawla Kuszewica z Chelmna, S. 70 .

${ }^{90}$ Ibidem, S. 71. ні спадкоємці чоловіка розділять майно поміж себе. Але якщо дитина народилася в час до десяти місяців і двох днів, почавши відрахунок від дев'ятого дня по смерті батька, або якщо також раніше народиться, аніж термін десять місяців і два дні спливе, тоді цей плід має бути визнаний від чоловіка, i буде ця дитина (якщо живою народиться) з іншими частку брати. Якщо ж помре, тоді частка іiі на матір перейде. А допоки вище окреслений час не мине, доки вдова не народить, доти в спокої без жодних поділів чоловікового майна має жити» ${ }^{85}$. Якраз у даному випадку вирішальними були саме підрахунки, а не присяга. Гроїцький пояснює цю норму численними фактами ошуканства з боку жінок, коли вони, щоб якомога довше залишатися у маєтках померлого чоловіка, вигадували вагітність і навіть імітували іiі. Натомість спадкоємці померлого не менше були зацікавлені в тому, щоб не допустити новонародженого до поділу батьківського майна. Відтак, вони могли вдаватися до обману, тому на перше місце виходили у справі раціональні докази. Ця норма відрізняється від середньовічних норм, відповідно до яких, присяги певної кількості свідків було достатньо для доведення справи.

Подібну норму наводить і Павло Щербич, однак зазначає, що деякі нащадки рахують час вагітності дев'ять місяці і два чи три дні від дня смерті батька, а як пізніше дитина народиться, то iㅣ до поділу батьківського майна уже не допускають. А це не зовсім вірна норма, як вважає правник, посилаючись на «поради мудрих людей», бо «жінка плід носити може десять місяців і два дні найдовше». Саме так і треба рахувати час вагітності, починаючи від восьмого дня від смерті батька ${ }^{86}$. Натомість, підкреслює Щербич, «якби якась жінка вийшла заміж і за короткий час по тому чоловік би помер, тоді, якщо вона раніше народить, аніж даний час вийде, рахуючи від дня весілля чи шлюбу, тоді таку дитина треба сприймати, як тих, хто пізніше народився» ${ }^{87}$. Отже, ця норма не враховувала можливості народження недоношених немовлят.

А для того, щоб сумнівів у вагітності від померлого чоловіка навіть не виникало, то жінка після його смерті, відчуваючи, що вагітна, протягом тридцяти днів мала прийти до суду і заявити про свій стан. I якщо це бувало доведено, то вона могла залишатися в маєтках чоловіка, щонайменше до народження дитини ${ }^{88}$.

Поблажливішим до дітей так званого «злого ложа» було хелмінське право. Відповідно до його приписів, ці діти, так само, як їхні брати чи сестри 3 «правдивого ложа» могли успадкувати свою частку материнського майна, незважаючи на те, чи народилися вони до шлюбу батьків, чи тоді, коли вони були у шлюбі ${ }^{89}$. Навіть більше, право деяким з них давало шанс, умовно кажучи, змінити статус і стати законнонародженими, але лише в тому разі, якщо батьки таки побралися: «Якби хто зачав дітей з наложницею, а потім би з нею одружився, і зачали з нею інших дітей, тоді перші діти мають вважатися законнонародженими в подружжі, яке потім наступило. Тому якщо потім батько помре, тоді так само перші діти, як і останні однаково до успадкування допускаються відповідно до права» ${ }^{90}$.

За уявленнями XVI ст. дитина також мала право на належне виховання. Саме в цьому контексті варто розуміти приписи місь- 
${ }^{91}$ Groicki, B. Oborona sierot i wdów, S. 49.

92 Щоправда ця теза Ф.Ар'єca, як і його твердження, що дитинство є відриттям ранньомодерної доби, зазнала критики зокрема у польській історіографії. Детальніше див.: Korczak-Siedlecka, J. Model wychowania dziewcząt w szesnastowiecznej Polsce, S. 50.

93 Детальніше див.: Арьес, $\Phi$. Ребенок и семейная жизнь при старом порядке, С. 49-50. кого права, за якими, якщо батько помер, а мати вела негідний спосіб життя, то їй не можна було доручати опіку над дітьми, і навіть, коли вона вже таке опікунство отримала, то іiі треба було відсторонити від опікунських обов' язків, і основним імперативом у цьому вказувалася турбота про дитинуํ. Таке ставлення до дитини, як уже зазначалося, кардинально відрізнялося від ставлення і поглядів середньовічної людини, коли про дитину не думали як про повноцінну людину ${ }^{92}$. Як зазначав Ф.Ар’єс, дитина так мало означала для середньовічної сім’, що померле немовля, особливо якщо воно ще було нехрещеним, закопували де попало, навіть під порогом чи в саду, як тіла домашніх тварин. «Немовля так мало значило і було зв'язане із життям такими тонкими нитками, що ніхто й не боявся, що воно повертатиметься після смерті, щоб докучати живим» ${ }^{93}$. Однак ставлення до дітей, навіть ненароджених, у кодексах міського права в XVI ст. уже зовсім інше.

По суті, це було відображення нової сторінки в історії дитинства та в історії почуттів. Саме у XVI ст. з'являються портрети померлих дітей, що означає, що за ними сумували і до них уже не ставилися, як до побічного продукту життя. I хоч від XIII до XVII ст. дитяча смертність і далі залишалася доволі високою, та глибока християнізація звичаїв і повсякдення спричинила зміну ставлення до особистості дитини.

Таким чином, ставлення до дитинства і до дітей еволюціонує від пізнього середньовіччя до ранньомодерної доби, і це якнайкраще відобразилося у кодексах міського права. Станом на XVI ст. дитина з'являється не лише в образотворчому мистецтві, а й у праві. Їі інтереси право не тільки обумовлює, а й активно захищає, розглядаючи різні нюанси, в тому числі такі, як право ненародженої, але зачатої, дитини, дітей правдивого ложа, сиріт тощо. Міським правом XVI-XVII ст. були захищені і майнові інтереси дитини, i iii життя та майбутнє, оскільки дитину не можна було стратити, i їй було гарантовано отримання фаху відповідно до їі походження. Отже, кодекси міського права XVI - першої половини XVII ст., хоч і декларують свою залежність від правових норм попередніх епох, однак містять чимало положень, що з'явилися у суспільстві тільки з приходом ідей Гуманізму і Реформації. Це добре прослідковується на прикладі відображеного на сторінках цих кодексів ставлення до дитинства і до прав дітей.

\section{References}

Adadurov, V. (2002) Istoriia Frantsii. Korolivs'ka derzhava ta stvorennia natsii (vid pochatkiv do kintsia XVIII st.). L'viv.

Ar'es, F. (1999). Rebenok i semeinaia zhizn' pri starom poriadke. Ekaterinburg.

Bardach, J. (1999). Statuty litewskie a prawo rzymskie. Lacina $w$ Polsce. Zeszyty Naukowe, pod. red. J.Axera. Zeszyt 7-9. Pomniki prawa doby Renesansu w Europie Środkowo-Wschodniej. Warszawa: OBTA. 9-165.

Bastl', B. (2004). Vik. Novyi chas // Istoriia yevropeis'koi mental'nosti / Za red. P.Dintsel'bakhera. L'viv. S. 263-271.

Bernard Klervoskii (2009). O blagodati i svobodnom vybore. Bernard Klervoskii. Traktaty, pod red. Iu. Romasheva. Sankt-Peterburg. 136-228. 
Bessmertnyi, Iu. (1991). Zhizn' i smert'v srednie veka: ocherk demograficheskoi istorii Frantsii. Moskva.

Clarke, J. (2004). Histories of Childhood. Childhood Studies: An Introduction, ed. by D. Wyse. Malden, MA; Oxford, UK. 3-12.

Cunningham, H. (2014). Children and Childhood in Western Society Since 1500. London: Routledge.

Deliumo, Zh. (2003). Grekh i strakh: Formirovanie chuvstva viny i tsivilizatsii Zapada (XIII-XVIII vv.). Ekaterinburg.

Diiannia ryms'ki. Khrystyians'ki prytchi Seredn'ovichchia (2014), per. z lat. R. Paran'ko. L'viv.

Erazm Rotterdams'kyi. Pokhvala hlupoti, per. V.Lytvynova. Retrieved from: http://www.ae-lib.org.ua/texts/erasmus fool_ua.htm\#15.

Godek, S. (2013). Prawo rzymskie w Pols ce przedrozbiorowej w świetle aktualnych badań. Zeszyty Prawnicze. Nr. 13/3. 39-64.

Groicki, B. (1954). Artykuły prawa majdeburskiego, które zowią Speculum Saxonum z łacińskiego języka na polski przełożone i znowu drukowane roku pańskiego 1629. Groicki B. Artykuły prawa majdeburskiego. Postępek sądów około karania na gardle. Ustawa płacej u sądów. Warszawa.

Groicki, B. (1958). Oborona sierot i wdów. Warszawa.

Groicki, B. (1953). Porządek sądów i spraw miejskich prawa majdeburskiego w Koronie Polskiej. Warszawa.

Groicki, B. (1954). Tytuły prawa majdeburskiego. Warszawa.

Gurevich, A. (2005). Individ i sotsium na srednevekovom Zapade. Moskva. burg.

Gurevich, A. (2007). Izbrannye trudy. Srednevekovyi mir. Sankt-Peter-

Hoshko, T. (2017). "Saksons'ke Zertsalo": symvoly i metafory. Ukrains 'kyi istorychnyi zhurnal. № 2. S. 126-141.

Ivanyts'kyi, S. (1925). Zakony pro opiku nad nedolitkamy v dzherelakh Magdeburz'koho prava Zakhidn'oi Rusy i Het'manschyny. Pratsi Komisii dlia vyuchuvannia istorii zakhidn'o-rus 'koho ta vkrains'koho prava. Vyp. 1. Kyiv. 59-81.

Korczak-Siedlecka, J. (2014). Model wychowania dziewcząt w szesnastowiecznej Polsce. Odrodzenie i Reformacja w Polsce. T. LVIII. 49-71.

Maksim Grek, Prepodobnyi. Raznye sochineniia. Retrieved from: http:// www.biblioteka3.ru/biblioteka/maksim_grek/razn_soch/txt10.html\#a45.

Mamycheva, D. (2013). Detstvo - metamorfozy kul’turnogo vzgliada. Taganrog.

Masliichuk, V. (2010).Vik doroslishannia: pochatok povnoi kryminal'noi vidpovidal'nosti v Livoberezhnii ta Slobids'kii Ukraini u druhii polovyni XVIII st. Ukrains 'kyi istorychnyi zhurnal. № 2. 38-47.

Masliichuk, V. (2011). Dytyna na Pivnichnomu Livoberezhzhi v druhii polovyni XVIII st. Siverians ’kyi litopys. № 2. 63-68.

Modrzewski, A. F. O poprawie Rzeczypospolitej, tłum. C. Bazylik. Retrieved from: https:/wolnelektury.pl/katalog/lektura/o-poprawie-rzeczypospolitej.html\#footnote-idm140071968

O'Neill, Y. V. (1965). The History of the Publication of Bernard of Gordon's Liber de Conservatione Vitae Humanae. Sudhoffs Archiv für Geschichte der Medizin und der Naturwissenschaften. Bd. 49. H. 3 (September). 269279.

Prawa Chelmienskiego poprawionego y z lacinskiego ięzyka na polski przetlumaczonego, xiąg piecioro ku pospolitemu pozytkowi przez Pawla Kuszewica z Chelmna (1623). Poznań.

Saksonskoe zertsalo. Pamiatnik, kommentarii, issledovaniia (1985), pod red. V. M. Koretskogo; per. L. I. Dembo. Moskva.

Sears, E. (1986). The Ages of Man: Medieval Interpretations of the Life Cycle. Princeton. 
Serdiuk, I. (2009). "Bez zaplaty, na kharchakh i odezhi khoziaiskikh": dity v naselenni livoberezhnoho ukrains'koho mista XVIII st. Kraieznavstvo. № 1-2. 196-202.

Serdiuk, I. (2011). Polkovykh horodov obyvateli: istoryko-demohrafichna kharakterystyka mis'koho naselennia Het'manschyny druhoi polovyny XVIII st. Poltava.

Serdiuk, I. (2012). Dytyna i dytynstvo v Het'manschyni XVIII st. Povsiakdennia rann'omodernoi Ukrainy. Istorychni studii v 2-kh tomakh. T.1: Praktyky, kazusy ta deviatsii povsiakdennia. Kyiv. 57-86.

Shahar, S. (2004). Growing Old in the Middle Ages. 'Winter Clothes Us in Shadow and Pain'. London; New York.

Skazanie o sotvorenii Bogom Adama. Retrieved from: http://apokrif.fullweb.ru/apocryph2/adam.shtml.

Sowina, U. (2002). Wdowy i sieroty w świetle prawa w miastach Korony w późnym średniowieczu i wczesnej nowożytności. Od narodzin do wieku dojrzałego. Dzieci i młodzież w Polsce. Cz. 1. Od średniowiecza do wieku XVIII. Praca zbiorowa, pod red. M. Dąbrowskiej i A. Klondera. Warszawa. 15-28.

Statuty Velykoho kniazivstva Lytovs'koho u 3-kh tomakh (2002). T. I: Statut Velykoho kniazivstva Lytovs'koho 1529 roku, za red. S. Kivalova, P. Muzychenka, A. Pan'kova. Odesa.

Statuty Velykoho kniazivstva Lytovs'koho u 3-kh tomakh (2003). T. II. Statut Velykoho kniazivstva Lytovs'koho 1566 roku, za red. S. Kivalova, P. Muzychenka, A. Pan'kova. Odesa.

Statuty Velykoho kniazivstva Lytovs'koho u 3-kh tomakh (2004). T. III: Statut Velykoho kniazivstva Lytovs'koho 1588 roku u 2-kh knyhakh. Kn. 1, za red. S. Kivalova, P. Muzychenka, A. Pan'kova. Odesa.

Szczerbic, P. (2011). Ius Municipale, to jest prawo miejskie majdeburskie, nowo z łacińskiego i z niemieckiego na polski język z pilnością i wiernie przełożone, wyd. G. M. Kowalski. Kraków.

Szczerbicz, P. (1581). Speculum Saxonum albo Prawo Saskie y Maydeburskie, porządkiem obiecadla z łacińskich y niemieckich exemplarzow zebrine, a na polski język z pilnośćią y wiernie przełożone. Lwów.

The Etymologies of Isidore of Seville (2006), translated, with introduction and notes, by S. A. Barney, W. J. Lewis, J. A. Beach, O. Berghof. Cambridge.

Usachev, A. (2014). "Starost' glubokaia” v XIV - XVI v.: demograficheskie realii i ikh vospriiatie sovremennikami (na materialakh pis'mennykh istochnikov). Drevniaia Rus’. Voprosy medievistiki. № 1 (55). 58-68.

Voronchuk, I. (2014). Instytut opiky: pravovi normy ta povsiakdenni praktyky na Volyni rann’omodernoi doby. Ukraina v svitovii istorii. № 3 (52). 134-150.

We Three Kings of Orient Are. Retrieved from: https://www.amalgama-lab.com/songs/b/blackmore_s_night/we_three_kings_of_orient_are. html

Zamura, O. (2014). "Velykyi shalenets"”. Smert' i smertnist' u Het'manschyni XVIII stolittia. Kyiv.

\section{Tetiana Hoshko}

\section{THE VISION OF THE CHILDHOOD IN THE CODES OF THE URBAN LAW IN THE RZECZPOSPOLITA IN XVI - EARLY XVII CENTURY}

Codes of Urban Law of the Rzeczpospolita of XVI - early XVII centuries reflected the evolution of ideas about childhood from the late Middle Ages to the early modern era. Although they refer to the legal norms of previous ep- 
ochs, however, they contain many provisions that came under the influence of Humanism and the Reformation. As a result of deeper Christianization of morality at the turn of the Middle Ages and the New Age, a new attitude towards childhood appears, as to a special and important stage in human life. Therefore, as of the XVI century, in legal codes there are special articles about children. City law begins to protect the interests of children by considering various aspects, in particular the rights of the unborn but conceived child, the children of the "true bed», orphans, etc., the property interests of the child, his life and the future.

Key words: Middle Ages, early modern era, Rzeczpospolita, stages of life, childhood, urban law, guardianship, adolescence, crime, punishment, pregnant woman, material interests of children, children of «true bed». 